\title{
GGU's aktiviteter i 1991
}

\author{
Martin Ghisler
}

Direktør

GGU's arbejde har i 1991 været præget af en opfølgning af de politiske bestræbelser på at opnå øget aktivitet på råstofområdet. Al geologisk information om Grønland registreres i GGU og søges præsenteret i en let tilgangelig form for olie- og mineselskaber.

På baggrund af en ny råstoflov for Grønland, vedtaget i 1991 af både Folketinget og Det Grønlandske Landsting, er der skabt gunstige betingelser for en $\emptyset \mathrm{get}$ interesse for råstofefterforskning hos den internationale industri. GGU har i 1991 udarbejdet informationsmateriale, både på det oliegeologiske område med henblik på kommende udbudsrunder vedrørende Vestgrønland, og på området 'hårde' mineraler med henblik på at tiltrække nye selskaber.

I forbindelse med GGU's informations- og servicevirksomhed over for den internationale olie- og mineindustri kan nævnes følgende:

- opbygningen af geologiske databaser er videreført, og som et led heri er der især arbejdet med indf $\varnothing$ jelsen af vigtige mineralfund fra $\varnothing_{\text {st- }}$ og Nordgrønland,

- videreudbygning af borekernearkivet omfattende kerne-prøver og håndstykker fra tidligere prospekterings-aktiviteter,

- udarbejdelse af en række oversigtsrapporter vedrørende kendte mineralforekomster samt baggrundsdata for prospektering af eventuelle mineralforekomster,

- opbygning af en seismisk/geologisk database omfattende oliegeologisk og efterforskningsmæssigt relevante data,

- udarbejdelse af en oversigt over alle tilgængelige geodata fra Grønland til Hjemmestyrets serie 'Trade and Industry in Greenland',

- et bidrag vedrørende geologisk baggrundsmateriale til en håndbog for investorer i Grønland udarbejdet af Mining Journal Research Services, udsendt af Råstofforvaltningen for Grønland,

- videreførelse af informationsservicen over for olieindustrien ved udsendelse af to nyhedsbreve omhandlende oplysninger og resultater af relevans for kulbrinteområdet (GHEXIS).
Der er gennemført en række forskningsprojekter vedrørende de geologiske og ressourcemæssige forhold i

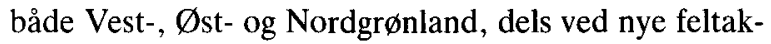
tiviteter, dels ved bearbejdelse af tidligere indsamlet materiale. I alt deltog 58 videnskabelige og tekniske medarbejdere i GGU's ekspeditioner i 1991.

GGU har på vegne af Råstofforvaltningen for Grønland ført tilsyn med udenlandske mineselskabers aktiviteter i Kangerlussuaq-området i Østgrønland og ved Narsaq i Sydgrønland.

På grund af manglende bevillinger har GGU i løbet af 1991 måttet reducere den faste medarbejderstab med ni ansatte.

I Vestgrønland gennemførtes GGU's største feltaktivitet i 1991 i Disko Bugt-området. Med udgangspunkt i det forladte udsted Atâ blev der udført både geologisk kortlægning og råstofundersøgelser og feltarbejdet vedrørende de basale geologiske og geofysiske unders $\emptyset$ gelser og de malmgeologiske specialunders $\varnothing$ gelser blev afsluttet. Projektet gennemførtes i nært samarbejde med geologer og studerende fra Københavns Universitet, hvor første del af feltarbejdet blev udført i somrene 1988-89. Der blev på det sydlige Nûgssuaq fundet en hidtil ukendt guldførende horisont, som i 1992 gøres til genstand for nærmere undersøgelser af et udenlandsk mineselskab. Fornyede oliegeologiske unders øgelser blev gennemført på Nûgssuaq og Svartenhuk med henblik på en vurdering af de geologiske forhold på de tilgrænsende sokkelområder.

Syd for Qasigiannguit/Christianshåb gennemførtes med henblik på lokalisering af mineralforekomster geokemisk prøveindsamling af elvsand og vand $i$ et 6000 $\mathrm{km}^{2}$ stort område.

I et område mellem Fiskenæsset og Ravn Storø undersøgtes udvalgte geologiske formationer, som er særlig interessante $\mathrm{i}$ forbindelse med mulige mineralforekomster af guld, platinmetaller, kobber og zink. Sideløbende med de geologiske undersøgelser gennemf $\varnothing$ rtes indsamling af sandprøver, vandprøver og tungmineraler fra elvløb med henblik på afgrænsning af områder med eventuelt særlig høje metalindhold. 
GGU bistod endvidere Grønlands Hjemmestyre i feltundersøgelser vedrørende muligheden for at anvende grønlandske bjergarter til en mulig produktion af facade- og gravsten, samt $i$ en vurdering af anvendelsen af specielle industrimineraler.

Glaciologiske undersøgelser er blevet videreført henholdsvis nord for Ilulissat/Jakobshavn og syd for Nuuk/ Godthåb. Undersøgelserne er dels et led i de igangvarende vurderinger af vandkraftpotentialet, dels et dansk bidrag til den internationale klimaforskning, især omkring drivhuseffektens indflydelse på globale havstigninger.

Med finansiel støtte fra Råstofforvaltningen for Grønland blev der ved hjælp af inspektionsskibet Thetis med Nunaoil A/S som operatør indsamlet supplerende seismiske data $(337 \mathrm{~km})$ mellem $63^{\circ}$ og $66^{\circ} \mathrm{N}$ ud for Vestgrønland.

I Østgrønland igangsatte GGU i samarbejde med Danmarks Geologiske Unders $\emptyset$ gelse og med finansiel støtte fra råstofforvaltningen et bassinmodellerings studie i Jameson Land. I forbindelse hermed foretoges supplerende geokemisk prøveindsamling. Der er i årets løb udarbejdet en 'Exploration Report' om Jameson Land bassinets oliepotentiale; i denne gives en samlet oversigt over alle for olieindustrien relevante geologiske og geofysiske informationer.

I Kangerlussuaq-området i Østgrønland indsamledes supplerende prøvemateriale for nærmere at undersøge nogle af dannelsesprocesserne ved de ædelmetalforekomster, som mineindustrien har interesse $i$.

I Nordgrønland blev der i det østlige Peary Land påbegyndt fornyede oliegeologiske unders $\emptyset$ gelser i et fælles feltprojekt med geologer fra Københavns Universitet. Studiet skal dels tilvejebringe et grundlag for en vurdering af oliepotentialet $i$ området, dels støtte tolkningen af seismiske data indsamlet af KANUMASprojektet i den nordlige del af den østgrønlandske sokkel.

I det vestlige Peary Land er indsamlet prøver af sjældent fossilmateriale fra jordens oldtid, i samarbejde med internationale specialister, og med støtte fra Carlsbergfondet.

I 1991 har GGU udgivet to geologiske kortblade i henholdsvis 1:500 000-serien (Thule) og 1:100 000-serien (Svartenhuk). Der er udkommet to bulletiner, fire rapporter og 10 bidrag i Open File-serien. Som resultat af GGU's aktiviteter er der desuden publiceret 24 artikler $\mathrm{i}$ internationale fagtidsskrifter.

\title{
Review of the Survey's activities in 1991
}

\author{
Martin Ghisler
}

Director

The new Mining Law for Greenland, approved in 1991 by the Danish and Greenlandic governments, was designed to encourage interest in exploration and utilisation of mineral resources in Greenland by creating more favourable operating conditions for the oil and mining industry. The activities of the Geological Survey of Greenland (Grønlands Geologiske Undersøgelse, GGU) in 1991 have reflected this new strategy. In the hydrocarbon field a new information prospectus has been prepared for the forthcoming licensing round for selected areas offshore West Greenland, while initiatives to attract interests of mining companies have been intensified.

GGU has continued to facilitate ready access by industry to relevant geological, geophysical and geochemical data held by the Survey. In 1991 this has included:
- enhancement of GGU's geological databases, in particular with inclusion of important mineralisation records from East and North Greenland;

- expansion of the drill core facility in Copenhagen, which incorporates drill cores and hand samples from earlier mining and exploration activities;

- preparation of a series of reports on known mineral occurrences, and compilations of geochemical and other data on specific areas as an aid to mineral prospecting;

- preparation of a seismic-geological database with special relevance to hydrocarbon prospecting;

- a review of all available geological data for Greenland for publication in the Home Rule Authority series 'Trade and Industry in Greenland';

- contributions of basic geological information for 